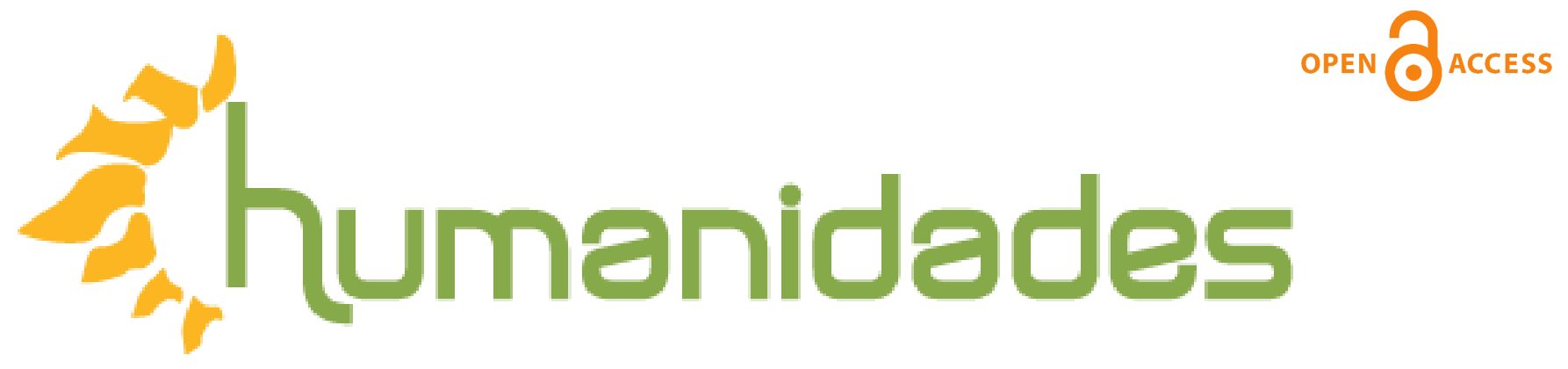

Revista de la Escuela de Estudios Generales, Universidad de Costa Rica

Enero-junio, 2018 •Volumen 8, número 1 • EISSN 2215-3934 •pp. 1-22

Recibido: 26-Septiembre-2017 Aceptado:15-Diciembre-2017

\title{
Formas de recordar la guerra: violencia en la fotogra- fía y el cine documental de la Revolución mexicana
}

DOI: http://dx.doi.org/10.15517/h.v8i1.31466

\section{Daniel Avechuco Cabrera}

Departamento de Letras y Lingüística de la Universidad de Sonora

Correo electrónico: daniel.avechuco@capomo.uson.mx

Todos los derechos reservados. Universidad de Costa Rica. Esta revista se encuentra licenciada con Creative Commons. Reconocimiento-NoComercial-SinObraDerivada 3.0 Costa Rica. Correo electrónico: humanidades@ucr.ac.cr / Sitio web: http://revistas.ucr.ac.cr/index.php/ humanidades 


\title{
Formas de recordar la guerra: violencia en la fotografía y el cine documental de la Revolución mexicana
}

\section{Resumen}

La fotografía y el cine documental tuvieron un papel protagónico en la construcción de la memoria de la Revolución mexicana y la definición de la nueva identidad nacional. Esta etapa construcción y definición supuso privilegiar y marginar ciertas imágenes, a la vez que, gracias a su ambigüedad o su debilidad semántica, se les reasignó significados a otras, con el propósito de forjar una Revolución favorable, es decir, una Revolución que corroborara las premisas de la retórica nacionalista. El presente artículo analiza cómo este proceso de “edición” repercutió en las representaciones de la violencia de la fotografía y el cine documental, uno de los aspectos más polémicos del movimiento revolucionario en tanto que, además de caos, evidencia proyectos culturales, políticos y sociales incompatibles
Palabras claves: documental, fotografía, revolución, violencia.

\section{Ways to remember the war: violence in photography and documentary film of the Mexican Revolution}

\begin{abstract}
Photography and documentary film had a leading role in the construction of the memory of the Mexican Revolution and the definition of the new national identity. This stage of construction and definition meant privileging and marginalizing certain images, while, thanks to their ambiguity or semantic weakness, they were reassigned meanings to others, with the purpose of forging a suitable Revolution, that is, a Revolution that corroborated the premises of nationalist rhetoric. This paper analyzes how this process of "editing" had repercussions in the representations of the violence of photography and documentary film, one of the most polemical aspects of the revolutionary movement to the extent that, besides chaos, shows incompatible cultural, political and social projects.
\end{abstract}

Keywords: documentary film, photography, revolution, violence, war 
Formas de recordar la guerra...

Tras una década de guerra civil, cambios de rumbo ideológico y zozobra, el Estado emprende un proceso de institucionalización con el propósito de alcanzar la solidez y la continuidad que las anteriores administraciones no habían conseguido. Las figuras que concentrarían el poder durante los primeros quince años de la posrevolución, Álvaro Obregón y Plutarco Elías Calles, eran conscientes de que la estabilidad del Estado dependía, en gran parte, de la reconciliación de los distintos bandos revolucionarios, que muy poco antes había luchado entre sí encarnizadamente. De esta certeza surge, con ayuda de una retórica populista y patriotera y una serie de actos conmemorativos y movidas de gran acierto político, una memoria revolucionaria homogénea, simple y no personalista, una memoria que escondía los irreconciliables proyectos sociales, políticos y culturales que habían dado pie a la pugna, y que, en cambio, ensalzaba virtudes que inducían al consenso, como la búsqueda de libertad o el sacrificio.

En este contexto José Vasconcelos, como cabeza de la Secretaría de Educación Pública, se dirige a los artistas para comunicarles que "la Nación os llama" y decirles que ya no deben buscar la inspiración "bajo el techo de la oficina del hogar, o en medio de la estupidez de los salones," sino en "la claridad de los cielos y la altura del monte" (1923, pp. 177-178). Un año después el Sindicato de obreros técnicos, pintores y escultores publica su conocido manifiesto en la revista El Machete, en el que secundan, a su manera, la propuesta vasconceliana:

Proclamamos que siendo nuestro momento social de transición
entre el aniquilamiento de un orden envejecido y la implantación
de un orden nuevo, los creadores de belleza deben esforzarse por-
que su labor presente un aspecto claro de propaganda ideológica
en bien del pueblo, haciendo del arte, que actualmente es una ma-
nifestación de masturbación individualista, una finalidad de belle-
za para todos, de educación y de combate. (Siqueiros, 1924, p. 4)

Estos llamamientos suponen el preámbulo de un par de sonadas polémicas - una en 1925 y otra en 1932 - en torno a la forma como debía concebirse el arte en el proceso de reconstrucción nacional. De estas polémicas saldrían victoriosos quienes, como Ermilo Abreu Gómez, propugnaban por los artistas que "unen sus esfuerzos al esfuerzo del pueblo que trata de levantar el edificio de la conciencia nueva de la nueva patria," aquellos que 
"buscan la expresión más propia, la que más conviene a una patria que lucha por definirse, definiendo su cultura y su aspiración superior" (1999, pp. 443-444). De la misma opinión era el arquitecto Manuel Amábilis, para quien "la misión de los artistas es poner al pueblo mexicano frente a frente de sí mismo y de su pasado y delante de los campos y de los cielos de su hogar patrio" (1925, p. 2). En consonancia con Abreu Gómez y Amábilis, Gabriel García Maroto sostenía que "la revolución [...] necesita de todo el esfuerzo de sus hombres para afirmar y organizar las virtudes que han motivado y justificado el hecho histórico" (1928, p. 45). Unirse al esfuerzo del pueblo, ponerlo frente a frente de sí mismo y afirmar y organizar las virtudes que han motivado y justificado el hecho histórico equivalía, con bastante frecuencia, a mostrarles a las masas el rostro más noble de la Revolución, razón por la cual Víctor Díaz Arciniega ve en los planteamientos de estos críticos y artistas nacionalistas una propuesta más política que estética (2010, p. 128).

A partir de los años veinte, pues, se va fortaleciendo un clima social, político y cultural que favorece las imágenes de la Revolución que elude el desorden y el divisionismo que prevalecieron en la década anterior. En la nueva producción cultural se intentará capturar no tanto el lado caótico de la Revolución como su trascendencia social, moral, espiritual e intelectual. En este nuevo enfoque del movimiento armado, la violencia como signo de arbitrariedad, desmesura y ruina cede su lugar a una violencia justiciera, punitiva y redentora, la cual está destinada a reconstruir la nación. Esta noción de violencia revolucionaria forma parte de lo que Guillermo Sheridan (1999) denomina ideologemas, conjunto de ideas, tonos, temas y pautas de representación recurrentes que fungen como parámetros legitimadores y que son reconocibles en muchas de los cuadros - visuales, musicales, verbales - sobre el conflicto. Cabe aclarar que esos ideologemas resultan más o menos transparentes dependiendo de la obra, el artista o la modalidad expresiva, y que en algunos casos es posible advertir resabios del pesimismo y el desasosiego que copan las representaciones de la década anterior. ${ }^{1}$ Esto sugiere que el canon de la Revolución no se implementó programáticamente, ${ }^{2}$ sino que la ubicuidad de su presencia tuvo inevitables repercusiones en el ambiente cultural posrevolucionario.

En los siguientes apartados intento explicar cómo la visión canónica de la Revolución impactó en la fotografía y el cine documental. El caso de estos dos medios de expresión es peculiar: mucho del material producido durante los años de actividad bélica fue reciclado durante las distintas etapas de 
Formas de recordar la guerra...

la posrevolución. Más allá de que esto hubo de ocurrir por razones obvias, conviene recordar que la reutilización de fotos y metraje supuso un elaborado ejercicio de ordenación, narrativización, reinterpretación, descontextualización y supresión, todo lo cual redundó, a menudo, en la gesta de una Revolución iconográfica desprovista de su inmensa e inaprensible complejidad. El sentido de las representaciones de la violencia, evidentemente, es una de las víctimas de este proceso de simplificación, como podremos ver a continuación.

\section{La fotografía de la Revolución: en busca de imágenes imperecederas}

El cataclismo que sacudió a muchas zonas del país desde finales de 1910 no inhibió la práctica fotográfica, cuya tradición mexicana se remonta a mediados del siglo XIX, sino todo lo contrario: desde el primer fogonazo rebelde, fotógrafos tanto profesionales como amateurs se sumaron a las distintas facciones con el propósito de capturar lo más significativo del movimiento armado. De este propósito resultó un acervo visual que, dadas su riqueza, su envergadura y su oscura lista de autores, aún es materia de estudio.

La intensa actividad fotográfica sin duda responde a diferentes causas, más allá de la mera pasión por la cámara. En primer lugar, hay que considerar el aspecto puramente comercial. Marion Gautreau explica que las revistas ilustradas, por ejemplo, encontraron en la foto con tema revolucionario una estrategia para aumentar las ventas: "Las revistas no pueden obviar la realidad de los enfrentamientos sin arriesgar su propia supervivencia. Además, las imágenes del conflicto suscitan una atracción mayor que las simples notas escritas" (2007b, p. 102). Por otro lado, la coyuntura incrementó la demanda de tarjetas postales: durante los primeros cinco años de rebelión, varios fotógrafos - algunos de ellos extranjeros, como Hugo Brehme y Walter H. Horne- se dedicaron a la producción y venta de postales. Estas tuvieron una exitosa acogida fuera de las fronteras mexicanas, por lo que el negocio se tornó bastante rentable. Debe tenerse en cuenta, además, que desde antes del estallido de la Revolución, era tendencia que los periódicos, especialmente los capitalinos, le dieran un espacio considerable a sucesos de violencia, como explica John Mraz: "Although the newspaper covered oficial acts of the president, the governors, ministers, and diplomats [...] pólice reports (nota roja) comprised its center. Its pages were filled with news of disasters, train crashes, streetcar accidents, fires, thefts, murders, suicides, and assaults" (2012, p. 21). 
Tampoco hay que olvidar la literatura de cordel, pliegos y hojas sueltas que contenían noticias sensacionalistas sobre crímenes tremebundos: homicidios, parricidios, canibalismo, fratricidios, riñas callejeras, violaciones, decapitaciones, envenenamientos... Los pliegos y las hojas sueltas, que adoptaban un tono moralista, estaban acompañados por ilustraciones llamativas que ponían en primer plano actos de violencia. De esta forma, es razonable especular que las fotos del conflicto armado tuvieron una rápida aceptación porque se insertaban en una tradición que hacía de las imágenes sobrecogedoras un bien de consumo.

Otro aspecto que explica la abundante producción fotográfica es la consciencia por parte de los distintos caudillos de que la imagen constituía una herramienta poderosísima en la incesante labor de adjudicarse legitimidad y de menoscabar la del bando contrario (Mraz, 2012, p. 40). Algunos caudillos incluso tenían a su fotógrafo de cabecera. Es el caso de Álvaro Obregón, cuyas campañas militares y actos protocolarios importantes siempre fueron cubiertos por Jesús H. Abitia, autor de varias fotos que contribuirán a inmortalizar la figura del Manco de Celaya en el imaginario canónico del conflicto armado. Además de la consciencia del valor propagandístico de la imagen, es probable que existiera un importante componente de vanidad; en El águila y la serpiente, Martín Luis Guzmán cuenta con sorna la afición de Venustiano Carranza por fotografiarse: “don Venustiano cultivó [...] tan tenaz y arrolladora inclinación a prodigarse en efigie, que su sonrisa bonachona y el brillo de sus espejuelos vinieron a ser en poco tiempo, para el agosto de los fotógrafos, verdadera alondra de luz: de luz áurea y tintineante" (2010, p. 227). Fuera maniobra propagandística o vanidad, el hecho es que del duplo caudi1lo-fotógrafo desembocó en imágenes que a la vuelta de algunos años cumplirían un papel primordial en el forjamiento de la Revolución canónica: Álvaro Obregón montado en un caballo a la orilla de un barranco, un hierático Emiliano Zapata con la indumentaria de charro y orlado con una espada, Pancho Villa y el líder zapatista posando juntos en la silla presidencial de Palacio Nacional, entre tantas otras.

Evidentemente, los fotógrafos no se limitaron al retrato; más abundantes todavía son las imágenes sobre batallas, auténticas o simuladas, y, muy especialmente, sobre las desastrosas consecuencias: edificios semiderruidos, montículos de cadáveres incinerados, fusilamientos, vías destruidas. Sobre este respecto, los periódicos y las revistas ilustradas realizaron una tarea capital, pues no solo hicieron posible que las fotografías gozaran de difusión, sino que además permitieron condicionar 
Formas de recordar la guerra...

propiciamente la interpretación de las imágenes gracias a los reportajes que acompañaban a las imágenes, a los comentarios al pie y a los elaborados — aunque muchas veces burdos - fotomontajes.

Cualesquiera que fueran las motivaciones de los fotógrafos, la realidad es que actualmente disponemos de una colección gigantesca con un alto contenido de violencia. En muchos casos se trata de fotos que no se conforman con satisfacer su responsabilidad informativa; hablamos de fotos en absoluto púdicas, dueñas de una morbosa pero al mismo tiempos muy benéfica consciencia del detalle: cabezas despedazadas, vísceras expuestas al sol, charcos de sangre, calles y plazas rebosantes de cuerpos baleados. Recordemos la célebre fotografía del cadáver del general maderista José Pérez Castro, perteneciente al archivo de los hermanos Cachú: en la zona donde debería estar el ojo derecho, hay un enorme boquete (figura 1). Otras fotos hacen convivir en el mismo recuadro cadáveres y la expresión envanecida y no pocas veces sonriente de quienes posan sabiendo que un fotógrafo está por inmortalizarlos. La pieza que con más claridad ejemplifica esta situación es la tétrica foto sobre un maderista colgado el primer de julio de 1913 en Pátzcuaro, Michoacán, también del archivo de los hermanos Cachú. A un lado del cadáver, un soldado bien vestido mira a la cámara con rostro de contenida emoción; atrás, hombres, mujeres y niños observan con cierta perplejidad no el cuerpo con el cuello roto que pende de un árbol, sino ese extraño aparato que les apunta con su único ojo (figura 2). En estos casos, el hombre colgante deviene en siniestro decorado, lo cual, sin embargo, no exime a la foto de tragedia o drama. Esta clase de composiciones encuentran su sentido en un contexto de guerra civil, que combina muerte y vida cotidiana con una armonía y naturalidad que resulta incómoda incluso con la distancia histórica de casi un siglo. 


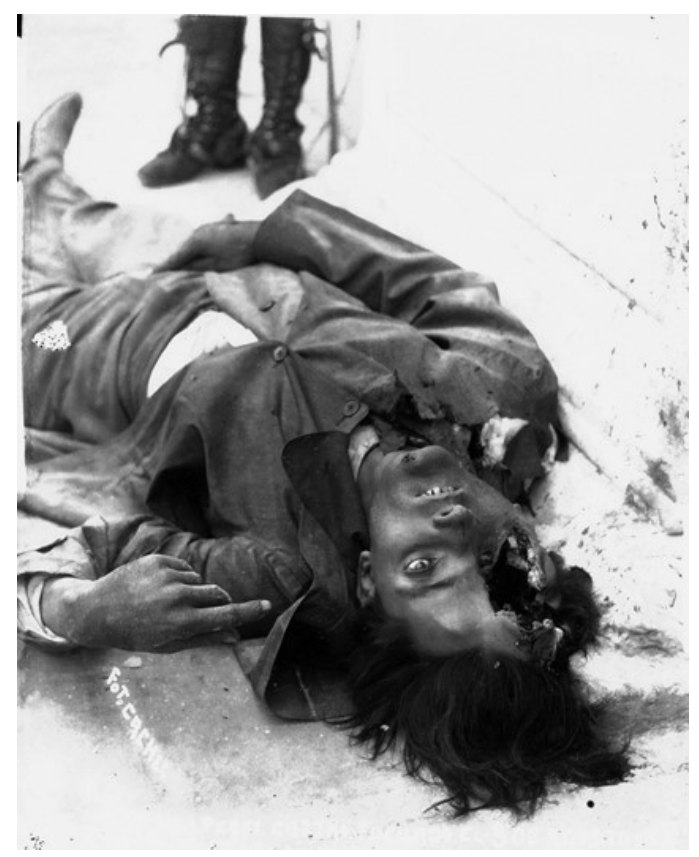

Figura 1: General José Pérez Castro, fusilado el 3 de agosto de 1914 en León, Guanajuato por el General Alberto Torres. Cachú hermanos. Fondo "Cachú-Ramírez Juan,” Departamento de Información y Documentación de la Cultura Audiovisual, Benemérita Universidad Autónoma de Puebla.

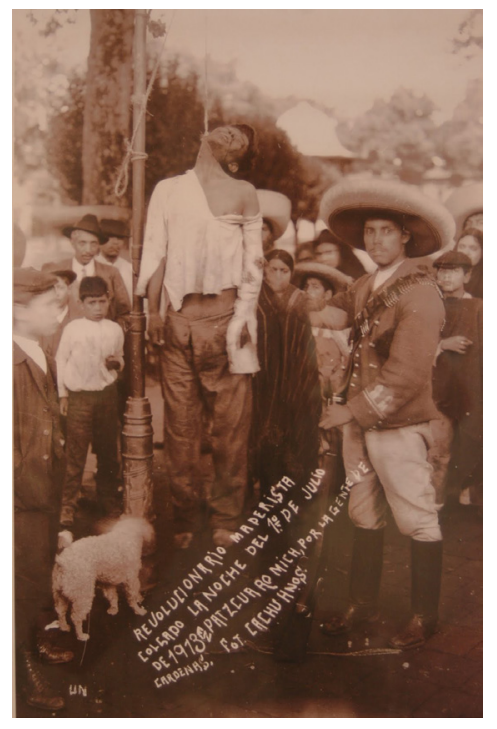

Figura 2: Revolucionario maderista colgado en la noche del $1^{\circ}$ de julio de 1913 en Páztcuaro, Michoacán, por la gente de Cárdenas. Cachú hermanos. Fondo “Cachú-Ramírez Juan,” Departamento de la Cultura Audiovisual, Benemérita Universidad Autónoma de Pueblo. 
Formas de recordar la guerra...

Como podemos observar, durante este primer periodo de actividad fotográfica abundan las fotos que hablan sobre caos, acorde con la situación inestable del país. Fotografías, por ejemplo, que recogen el saldo de la Decena Trágica ofrecen una imagen desoladora y sucia de la capital: el Zócalo tapizado de soldados y caballos muertos; cuerpos quemados a mitad de una calle cualquiera; edificios llenos de boquetes por las balas y los bombardeos. Son fotografías que testimonian no tanto una gesta épica como un cataclismo de proporciones monstruosas, y que en un balance general es posible que les ganen la partida a las fotos meticulosamente posadas que, por urgencias políticas o por mera vanidad, pretenden edulcorar la guerra y sus efectos y con ello mandar mensajes optimistas o disuasorios. Y es que a excepción de las "líneas editoriales" partidistas, que por supuesto tienen un radio de influencia menor y con fecha de caducidad, en esa primera fase de actividad fotográfica no hay una idea rectora que señale el rumbo que han de marcar las imágenes. La heterogeneidad del tono de las fotografías parece reflejar con claridad la existencia de varias revoluciones, es decir, de varios proyectos sociales, políticos y culturales.

El segundo periodo de actividad fotográfica se caracterizó, obviamente, ya no tanto por la producción de material, sino por la recuperación de fotos tomadas en la década anterior. A grandes rasgos, esta práctica de recuperación derivó en dos procedimientos: por un lado, la elaboración de historias ilustradas de la Revolución y, por otro, la exhibición y reiteración de fotografías semánticamente débiles o ambiguas y con una fuerte carga simbólica. Lo que hermana a ambos procedimientos es la desaparición o atenuación de la violencia, pese a que, según comentamos en los párrafos anteriores, un porcentaje considerable de la producción fotográfica estaba relacionado con destrucción de edificios, heridos y cadáveres. Sobre este tema, Marion Gautreau comenta:

Con la revisión de las revistas ilustradas en la Posrevolución, de 1921 a 1940, observamos que las fotografías de la violencia revolucionaria desaparecen por completo de las páginas que recuerdan o conmemoran el conflicto. Poco a poco, y desde los años de la presidencia de Carranza, que fue electo en 1917, los semanarios ilustrados vuelven a sus modelos de publicación anteriores a la Revolución. (2007b, p. 101)

Gautreau presume que las fotos alusivas a la violencia revolucionaria desaparecen porquelagente, hartadetantos años de convulsióny desasosiego, deja de consumirlas, yporquealudíanahechos puntualesquenopodíanerigirseensímbolos(2007a,p. 133). 
Sin duda la disminución de la demanda y sus ataduras referenciales coadyuvaron a que las representaciones más crudas de la violencia revolucionaria comenzaran a escasear o, cuando menos, a ser confinadas en sitios de mucha menor exposición. Sin embargo, el fenómeno también podría explicarse a partir de la eclosión del nacionalismo cultural revolucionario, una de cuyas manifestaciones fue el forjamiento de una memoria conciliadora. Por un lado, muchas de las fotos con contenido violento estaban relacionadas con alguna facción específica, y su exhibición iba en detrimento del mensaje de unidad nacional que el Estado lanzaba en su empeño por consolidarse; y por otro, esas imágenes de muerte y desorden se oponían al espíritu triunfalista y celebratorio que el canon revolucionario poseía. De aparecer en primer plano, pues, la violencia debía emitir los significados propicios.

En las historias ilustradas de la Revolución, la violencia ocupa un papel importante en el recuento de los sucesos, en tanto que se trata de rememorar una guerra, pero en ningún momento objeta el mensaje de unidad que se halla en la base. El iniciador de estas historias ilustradas fue Agustín Víctor Casasola, el autonombrado fotógrafo de la Revolución. En 1921 publica Álbum histórico gráfico, “el primer gran proyecto de historia gráfica realizado en la República" (2007a, 117). Con este álbum se pone la primera piedra a la canonización de un archivo que por muchos años se consideró como el repositorio de la memoria fotográfica de la Revolución, con todo lo que ello implicaba. En años más recientes, sin embargo, han ido apareciendo estudios que señalan que el archivo Casasola es el resultado del trabajo de un número muy grande de fotógrafos, y que la mitificación de ese apellido solo ha contribuido a simplificar el contenido de un acervo rico en matices, contradicciones y perspectivas sobre la guerra y sus consecuencias:

El mérito más importante de los hermanos Casasola es el haber fundado en México la primera agencia gráfica de prensa con características modernas de comercialización en el año de 1912. La compraventa de imágenes era su principal finalidad. De ella surgirían algunas de las siguientes características: adquisición de negativos a fotógrafos ajenos a la agencia, y estructuración de un archivo de cara a la venta de imágenes a la prensa nacional y extranjera. El primer caso se constituía en algo bastante similar al plagio o el robo de los derechos de autor, ya que en no pocos negativos del archivo el nombre original del autor aparece borrado y sobrepuesto el de los Casasola. Hasta la fecha se han identificado (no todos con nombre propio) más de cuatrocientos ochenta fotógrafos ajenos a la agencia, o por lo menos al apellido Casasola. (Arnal, 2010, p. 39) 
Formas de recordar la guerra...

El mito del archivo Casasola no solo constituye una injusticia para los casi quinientos fotógrafos que aportaron su arrojo, persistencia y talento para la conformación del acervo iconográfico, sino que también contribuye decisivamente a la simplificación de una cadena de acontecimientos muy compleja $y$, por lo tanto, imposible de condensar en un único y gran relato, por más que esté sustentado en la colección más copiosa de fotos. La simplificación de la Revolución, desde luego, presupone la simplificación también de la violencia. Al transformar el cúmulo de imágenes en una narración lineal, transparente, teleológica, con la descontextualización de rigor de algunas fotos semánticamente débiles, vagas o ambiguas y el "olvido" de otras tantas, la violencia adquiere un semblante plano y gracias a ello se convierte en un significante que convalida la lectura nacionalista, simplona, celebratoria y apolítica de la Revolución.

A la aparición de las historias gráficas de la Revolución habría que agregarles los álbumes que, también a partir de los años veinte, intentaron capturar la riqueza natural, antropológica y arquitectónica del México que había "destapado" el movimiento armado. Hugo Brehme es quizás la figura más importante de este fenómeno fotográfico, aunque cabría especular que lo estimula no tanto un ánimo nacionalista, sino una visión comercial. Como sea, sus álbumes ayudaron a la difusión de una imagen más amable tanto de los espacios mexicanos como de los actores sociales que la Revolución había sacado a la superficie. México pintoresco (1923), su álbum más conocido, es para algunos la obra fundadora de esta corriente fotográfica:

La mexicanidad exacerbada de Hugo Brehme contribuyó en parte a la generación de nuevos imaginarios de reafirmación cultural nacionalista, que tuvieron expresión lo mismo en las denominadas Escuelas al Aire Libre promovidas desde 1913 por Alfredo Ramos Martínez, que en el muralismo encabezado por Orozco, Rivera y Siqueiros en los años veinte, o el Taller de Gráfica Popular, surgido después y lidereado por Leopoldo Méndez y Pablo O’Higgins, pintores y grabadores que popularizaron aún más ciertos íconos brehmenianos. (Casas, 2007, p. 181)

Dado que sus casi doscientas fotos se dedican a mostrar paisajes naturales, ruinas arqueológicas y tipos populares encuadrados desde una perspectiva que tiende a idealizar, México pintoresco se suma a los discursos enaltecedores del México posrevolucionario que rehúyen, en este caso hasta la negación, el terremoto bélico de hacía muy pocos años. 
Comentaba antes que además de la confección de historias gráficas, como las de la dinastía Casasola, la recuperación del movimiento armado tuvo como estrategia la exhibición y reiteración de ciertas imágenes. Algunas fotos acerca de la etapa militar de la Revolución aglutinaban características que, con el favor de la descontextualización y a veces mediante una interpretación contraria al origen real de la imagen, ofrecían el sentido apropiado según los intereses en juego: combates épicos, lugares de relevancia histórica, reconciliación de los caudillos, tragedia y drama dignificantes, perfiles "genuinamente mexicanos," etcétera. En gran medida gracias a la sobreexposición, estas fotografías pronto pasaron a formar parte del imaginario canónico de la Revolución, como asevera John Mraz:

Huge banners with the faces of Francisco I. Madero, Pancho Villa, and Emiliano Zapata hover over political rallies. Restaurant walls are flavored by sepia-tones reproductions of soldiers embracing their sweethearts in train stations. Bureaucrats in government offices labor under the gaze of legendary heroes. Hotel and bank lobbies are decorated with pictures of cavalrymen under wide-brimmed sombreros who rides their steeds through cornfields, while the unfailing soldaderas (camp-followers) walk alongside. Markets of folk art have the inevitable stall dedicated to vendors of washed-out, overexposed copies, often from the Casasola Bazaar, as well as other forms of visual history: postcards, calendars, posters, T-shirts, jackets, coffee mugs, ashtrays, and other bric-a-brac. Illustrated magazines and newspapers reproduced classic images constantly, as do the multitude of illustrated historias gráficas celebrating México's revolutionary past, where the pictures are fused with texts to instill a historia patria that will teach love of the fatherland. $(2009$, p. 5)

Este conjunto de imágenes conforma una estampa del conflicto armado propicia para la unidad nacional y el propósito de suturar las heridas, puesto que destaca los momentos altamente simbólicos - y por lo tanto memorables - del proceso revolucionario y relega aquellas imágenes que, por una parte, podrían reavivar la pesadumbre de quienes experimentaron directamente la furia de la Revolución y que, por otra, testimonian desorden, destrucción y muerte. En este imaginario canónico no tienen cabida, por ejemplo, las oscuras montañas de cadáveres (figura 4) ni los suelos tapizados de gente recién fusilada (figura 5): ambas estampas ponen en entredicho la naturaleza impetuosa pero redentora de la Revolución que habían confeccionado las élites políticas y culturales. 
Formas de recordar la guerra...

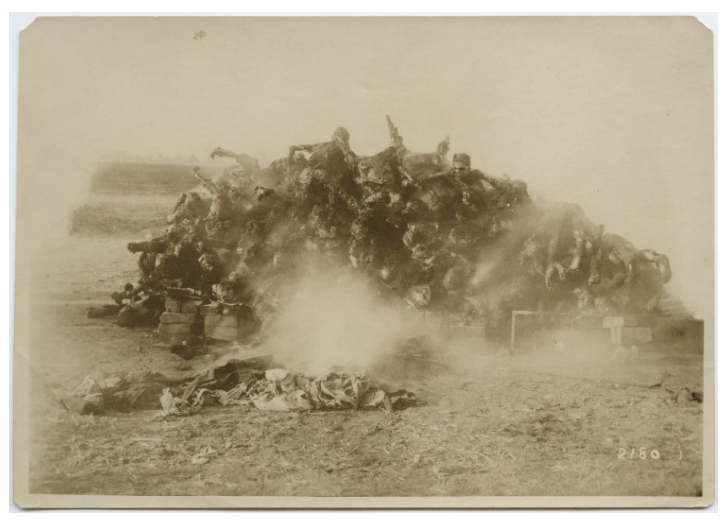

Figura 3: Burning the dead, c1910. Mexico View Co. DeGolyer Library, Sothern Methodist University.

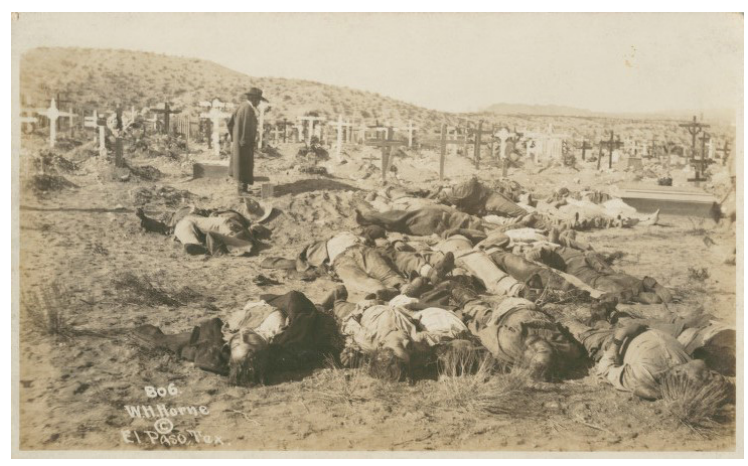

Figura 4: "Dead man in graveyard," 1913. Walter H. Horne. Southern Methodist University, Central University Libraries, DeGolyer Library.

Más allá de que algunas facciones contaron en sus filas con sus propios fotógrafos, y de que el vínculo entre estos y los caudillos desembocó en algunas imágenes ya inmortales, lo cierto es que en la manufactura de la iconografía canónica de la Revolución tuvo mayor peso la "expropiación" del material, que fue difundido luego de un largo quehacer de reajustes, descontextualizaciones, reescritura de pies descriptivos, supresiones y montajes. Las imágenes de este material constituyen un abigarrado relato donde la violencia revolucionaria no obstaculiza la labor de legitimación que el Estado había emprendido cuando la guerra finalmente cesó, y le da impulso al proceso de mitificación de la Revolución.

\section{El cine documental de la Revolución: antología y épica}


Desde los primeros compases de la Revolución, los líderes de los distintos bandos se percataron de las ventajas propagandísticas que podrían proporcionar las imágenes en movimiento, y no dudaron en incorporar a sus filas a profesionales de la cámara. Es conocida la anécdota según la cual Victoriano Huerta quiso hacerse del material fílmico de Salvador Toscano, consciente del daño que esas imágenes podrían hacerle a su causa (Wood, 2009, p. 63). Pero quizás el caso más famoso es el de Pancho Villa, quien en enero de 1914 firma un contrato de 25 mil dólares con la productora estadounidense Mutual Film Corporation, del cual derivaría la película The Life of General Villa (figura 5), dirigida por Raoul Walsh:

Los convenios con la Mutual obligaron a Villa a guerrear a horas determinadas y específicas: de las nueve de la mañana a las cinco de la tarde. De esa manera evitaban la oscuridad insalvable que habían tenido muchas de las imágenes anteriores. Gómez Palacio y Torreón fueron un par de ciudades filmadas en sendos combates. En la primera todo se llevó a buen fin. La segunda tuvo ecos trágicos, y las horas fijadas por la compañía estadounidense se hicieron añicos ante la bravura de los federales y villistas [...] los camarógrafos estaban aterrados y en un momento dado lo único que les importó fue ponerse a salvo de las balas amigas y enemigas. (Luna, 1984, p. 170)

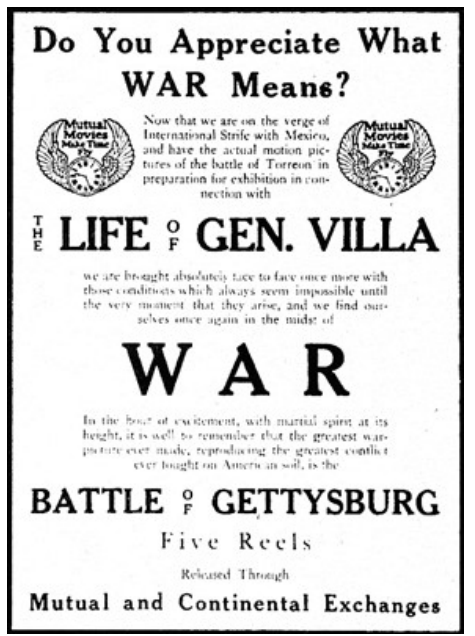

Figura 5: Cartel promocional de la película

Ya sea por un propósito meramente noticioso o ya por un afán propagandístico, el cine documental produjo horas y horas de metraje que consiguen capturar muchas de las diversas y muy contradictorias caras de la Revolución. Ahora bien, a diferencia de eventos de corte oficial, como la conmemoración de fechas históricas mediante desfiles o la firma de acuerdos o alianzas, que por naturaleza suponen 
Formas de recordar la guerra...

una puesta en escena que transmite sin dificultad alguna un mensaje claro, las imágenes destinadas a nutrir las películas de contenido bélico debían pasar por ejercicios de montaje que condicionaran la recepción de las imágenes. Este condicionamiento era reforzado por paratextos, entre ellos los anuncios periodísticos que avisaban acerca de la proyección de cierto documental. Tales anuncios no solo contenían los datos sobre la fecha y el lugar de la exhibición, sino que además ofrecían una breve sinopsis que de alguna manera encauzaban la lectura de las imágenes del documental, con frecuencia echando mano de la antigua y muy conocida estrategia de distribuir la violencia de acuerdo con los intereses que defendía el emisor del anuncio. Como ejemplo tenemos el "diálogo" que mantuvieron los documentales Sangre hermana (1914), de filiación huertista, y La Revolución zapatista (1914), cinta de propaganda zapatista. El primer filme, estrenado en el teatro Lírico, era publicitado en los siguientes términos: "El público podrá ver con claridad meridiana los horrores del zapatismo. Verá desfilar a nuestro valiente ejército trabando combate con los zapatistas; se verán los pueblos incendiados y el terrible castigo que reciben los culpables" (citado en Jablonska, 1997, p. 63). La segunda película fue proyectada en el teatro-circo Welton, y se promocionada así:

En esta primera película histórica nacional, sus tres mil metros tienen detalles altamente impresionantes. Ante la vista maravillada del público se reproducen escenas reales y verdaderas, llenas de dolor y de lágrimas. Sevenlos tremendos combates sostenidos por los combatientes zapatistas luchando por conquistar sus ideales y sus derechos conculcados. (citado en Jablonska, 1997, p. 72)

Al aludir a "los horrores del zapatismo," la propaganda de Sangre hermana se beneficia de la estampa que la clase media intelectual de la capital forjó del movimiento suriano, al que se consideraba, recordemos, poco menos que una horda ávida de sangre. Además, mediante el empleo del adjetivo posesivo, el anuncio se asegura, primero, de incluir al espectador en el bando federal (Fregoso, 2012, p. 127) y, segundo, de situar al ejército zapatista fuera del perímetro de la nación. La propaganda de La Revolución zapatista, en cambio, apela a la fibra sensible del público: dolor, lágrimas, ideales, derechos. Especula Berenice Fregoso que ambas obras eran visualmente muy similares, que, entre otras cosas, las dos contenían escenas de ahorcados, incendios y fusilamientos (2012, pp. 129-130). De ser cierto, este dato no haría sino confirmar la relevancia de los paratextos -boletines, sinopsis, antetítulos, reseñas periodísticas - en el encauzamiento 
de la interpretación de las imágenes de violencia. Como señala Zuzana Pick, fue una práctica muy común reciclar metraje durante los primeros años de la contienda (2010, p. 13), incluso para películas con tendencias políticas contrarias, y en ese sentido podemos decir que del poder de la apropiación y organización de imágenes en movimiento se tuvo consciencia mucho antes del nacionalismo cultural revolucionario, muy al contrario de lo que se suele afirmar.

Ahora bien, cuando no había de por medio intereses partidistas claros, el cine documental sacó provecho del lado más espectacular de la guerra para atraer público. Pese a que la Revolución había traído consigo toda clase de estragos, algunos propietarios de las películas buscaron captar el interés de la gente cubriendo las imágenes con un ropaje simplón y patriotero. El 15 de abril de 1915, el teatro Alcázar publica el siguiente anuncio en el periódico El Monitor: “¡Estreno! ¡Estreno! ¡Sensacional estreno! La toma de Torreón. Sangrientos combates que prueban la heroicidad de los contendientes. Película tomada en el campo de batalla. ¡Venid! ¡Venid!... ¡y quedaréis admirados del valor de los mexicanos...!" (citado en Jablonska, 1997, p. 74). Como observamos, el derramamiento de sangre y la heroicidad se parangonan, y la publicidad cierra con el apunte sobre la distintiva virilidad del mexicano, de la que tanto jugo sacará después el cine de ficción y en general el discurso nacionalista. Esta noción de la guerra revolucionaria como espectáculo sin duda ayudó a restarle solemnidad a la violencia y, en cambio, a dotarla de una dimensión épica que favoreció al entretenimiento pero que, al mismo tiempo, mermó sus posibilidades críticas.

La temprana tendencia a absorber material fílmico de la más variada procedencia para después transformarlos en relatos revolucionarios con una clara orientación política prepara el terreno para los documentales de naturaleza antológica que aparecerían a partir de los años cincuenta.3 Cintas como Memorias de un mexicano (1950), “obra póstuma” de Salvador Toscano editada por su hija Carmen, pretendieron en su momento ser el testimonio fílmico definitivo sobre la Revolución en tanto que ofrecían una supuesta narración no fragmentada del conflicto armado, sino el panorama completo (Wood, 2009, 9. 155). Independientemente de cuán ambiciosos e inviables fueran, proyectos de esa envergadura resultan congruentes en un contexto en el que la retórica oficial y el discurso de algunas élites culturales conciben la Revolución como un movimiento lineal, homogéneo y de contornos clarosEn vista de este contexto, se entiende que el narrador 
Formas de recordar la guerra...

de Memorias de un mexicano, por ejemplo, pase "por alto las causas políticas, sociales y económicas de la revolución, presentándola más bien como una riña fuerte pero pasajera entre la gran familia mexicana" (Wood, 2009, p. 158). Tampoco extraña que algunos años más tarde, el Instituto Nacional de Antropología e Historia proclamara la obra monumento histórico de México.

La canonización de un producto cultural, es decir, su ingreso al Gran Museo de la Nación, permite que sea consumido por más público, pero a la vez establece límites al conocimiento de la parcela de realidad que dicho producto refiere. En el caso de Memorias de un mexicano, el reconocimiento estatal de alguna manera valida el relato simplista de la Revolución que la película ofrenda. La cinta, en efecto, obvia la complejidad sociocultural que caracterizó al movimiento armado con la intención de construir una narración totalizante, nacionalista, apolítica y a ratos épica. Andrés de Luna habla de las tres grandes estrategias de edición - que él denomina macrorreglas - a que apelaron los antologadores, estrategias detectables en la obra en cuestión:

En primer lugar, la supresión, las artes y malabareos del montaje [...] permiten una adecuación y un encauzamiento. De esta manera los hechos se cuelan para que, una vez que posean una sintaxis y una retórica, logren la eficacia del significante vacío. Los personajes así quedan liberados de pesadas cargas, la Revolución queda sustentada en las imágenes que de ellas se quieren tener [...] la generalización contribuye a fincar, en un panorama bien soleado y con tierra fértil, las semillas del simplismo oficialista. De esta manera: todo cabe en una "versión" sabiéndola acomodar [...] La última parte de las macorreglas se refiere a la construcción en la que tiene mucho que ver la coherencia y la retórica. (1984, pp. 154-155)

En el caso de Memorias de un mexicano, habría que agregar la estrategia de la voz en off. Para explicar el rumbo errático del conflicto, el narrador apela a un lenguaje vago, como cuando la película aborda la Convención de Aguascalientes: "Pancho Villa y Emiliano Zapata no estaban de acuerdo con Carranza". Tras estas palabras, no se dice de qué naturaleza eran las diferencias, y algunos minutos después vemos las escenas de Zapata y Villa entrando a la capital del país, con música y vivas oportunamente sobrepuestos. 
No obstante que dotan a la película de una fluidez irrefutable, se trata de estrategias que contribuyen a la simplificación, lo cual, evidentemente, repercute en las representaciones de la violencia. En Memorias de un mexicano abundan las imágenes de cadáveres y edificios destruidos, sí, pero estas aparecen casi siempre para corroborar la exégesis nacionalista, épica y apolítica de la Revolución. La gran mayoría de las escenas de violencia se muestran en momentos donde el conflicto armado resulta transparente en su orientación, como la toma de Ciudad Juárez por las fuerzas maderistas, la primera gran victoria de la Revolución, o la Decena Trágica, consecuencia de la traición de Félix Díaz. En estos casos, además, la música, celebratoria o fúnebre, según convenga, colabora en la determinación de sentidos (Wood, 2009, p. 61). La violencia de Memorias de un mexicano, puesto en otras palabras, no crea conflicto ni pone en entredicho la unidad revolucionaria.

Como apunta Zuzana Pick, muchas de las películas documentales están construidas a partir de fragmentos pertenecientes a colecciones y archivos muy distintos (2010, p. 14). Inalterados, sin un montaje ni música cohesivos, sin un narrador ficticio intradiegético que establezca con su discurso una lectura de las imágenes, esos fragmentos quizás se encontrarían cerca de articular una desordenada, contradictoria y muy heterogénea Revolución, que en realidad no es una sino muchas, tantas como movimientos regionales hubo, cada uno con su propio proyecto social, político y cultural. En esa hipotética película, la violencia hablaría no de una guerra épica sino de caos, de una fuerza no patriótica sino desmesurada, destructiva $\mathrm{y}$ frecuentemente arbitraria.

René Girard afirma que una de las funciones del relato mítico consiste en otorgarle sentido a la violencia fundadora con el fin de hacerla digerible para los

\section{Conclusiones} grupos humanos que la ejercen en las fases de consolidación. La conciencia mítica mira al pasado y recupera los actos de violencia que dieron origen a la comunidad en cuestión para después convertirlos en narraciones. Estas, sin embargo, no tienen vocación histórica: las alienta la necesidad de construir una memoria que pueda evocar los inicios violentos sin el riesgo de desencadenar traumas colectivos. Es decir, el relato mítico no inventa, sino que reconfigura la realidad preexistente, apela a un orden de los eventos y una perspectiva narrativa que coadyuvan a la representación de una violencia como un acto necesario, razonable, a veces incluso digno de la remembranza orgullosa. 
Formas de recordar la guerra...

Acaso sin pretenderlo, las reflexiones de Girard sugiere una explicación de cómo los Estados-nación que resultan de un extenso y turbulento proceso revolucionario construyen discursivamente una tradición histórica y cultural sin rehuir los orígenes violentos. En el caso particular de México, el Estado, las élites culturales y en general los ciudadanos no solo no rehúyen esos orígenes, sino que además hacen de ellos la piedra angular de la nueva nación: la Revolución se recuerda, pero sobre todo se celebra. Esto es posible, precisamente, porque la rememoración del movimiento armado se realiza a través de relatos — verbales, musicales, fotográficos, pictóricos, cinematográficos- que reajustan el material histórico, y con ello domestican la violencia, la hacen admisible. Cabe decir que detrás de este lento, gradual, dinámico y complejo proceso de transfiguración del material histórico existe más que una argucia política para legitimar la monopolización del poder; sin duda también hay una necesidad antropológica del individuo de convivir con las manifestaciones de la violencia, especialmente con aquellas que le dan origen e identidad a su cultura.

Según pudimos advertir en los apartados anteriores, la fotografía y el cine documental tuvieron un papel protagónico en la recuperación de la lucha armada. Esto se debió al poder persuasivo y a las múltiples posibilidades divulgativas de la expresión visual, pero en especial a su ductilidad: la ambigüedad (Luna, 1984, p. 153) o la debilidad semántica (Mraz, 2012, p. 9) que caracterizan a muchas de las imágenes con tema revolucionario facilitó la reasignación de significados. Tras dicha reasignación, la violencia dejó de ser el testimonio más elocuente del desorden y la muerte y de incompatibles proyectos sociales, políticos y culturales, para convertirse en un elemento más de la puesta en escena

\section{Notas}

1. Un claro ejemplo es la novela de la Revolución mexicana, corpus en el cual predomina un tono pesimista, escéptico y desencantado, en evidente discordancia con el discurso encomiástico de la época. Y aun obras optimistas y celebratorias, como Cartucho (1932), de Nellie Campobello, divergen de las representaciones canónicas de la Revolución.

2. Descarto la teoría de un Estado mexicano autoritario durante los años veinte: concuerdo con Alan Knight en que antes de 1940, el grupo en el poder todavía no 
poseía la fuerza suficiente para dominar todos los frentes (2013, p. 531), mucho menos el de la memoria revolucionaria, aún muy viva con sus resentimientos, contradicciones y traumas.

3. Esta clase de documentales son casi tan antiguos como la Revolución misma, pero esas tempranas películas, dados los tiempos turbulentos, no gozaron de una gran difusión, y actualmente solo tenemos noticias de ellas gracias a las historias del documental mexicano, como la de Aurelio de los Reyes o la de Alejandra Jablonska y Juan Felipe Leal. Es el caso de Historia completa de la Revolución. De 1910 a 1915, de Salvador Toscano, cinta en la que, de acuerdo con la propaganda, se aprecia "los heroicos sacrificios llevados a cabo por el Ejército Legalista como continuación del Gobierno implantado por el Apóstol de la Democracia don Francisco I. Madero" (citado en Reyes, 1986, pp. 105106). Un año después es exhibió una segunda versión, titulada Historia completa de la Revolución. De 1910 a 1916, con metraje actualizado (Reyes, 1986). En 1923 Edmundo Gabilondo edita Revolución mexicana con rollos de película de los hermanos Alva, aunque se estrenó una década después (Luna, 1984).

\section{Referencias}

Abreu, E. (1932). El año artístico 1932 y las nuevas corrientes literarias en México. G. Sheridan (Comp.), México en 1932: la polémica nacionalista (pp. 440-446). México: Fondo de Cultura Económica.

Amábilis, M. (1925). Diego Rivera y su obra. El arquitecto, 34 (5), 1-2.

Arnal, A. (2010). Atila de tinta y plata. Fotografía del zapatismo en la prensa de la ciudad de México entre 1910 y 1915. México: Instituto Nacional de Antropología e Historia/Consejo Nacional para la Cultura y las Artes.

Benjamin, T. (2003). La Revolución mexicana: memoria, mito e historia. México: Taurus.

Casas, B. (2007). Hugo Brehme: el paisaje romántico y su visión sobre el mexicano. Dimensión Antropológica, 41, 171-201. Recuperado de https://revistas. inah.gob.mx/index.php/dimension/article/view/2326/2239 
Formas de recordar la guerra...

Díaz, V. (2010). Querella por la cultura "revolucionaria" (2 ed.). México: FCE.

Elías, P. (1988). Pensamiento político y social. Antología (1913-1936). México: FCE.

Fregoso, B. (2012). La película zapatista de Ocañas. Letras Históricas, 5, 123-132.

García, G. (1928). La obra de Diego Rivera. Contemporáneos, 1, 43-75.

Gautreau, M. (2007a). La Ilustración Semanal y el Archivo Casasola. Una aproximación a la desmitificación de la fotografía de la Revolución Mexicana. Cuicuilco, 14 (41), 114-140.

Gautreau, M. (2007b). ¿Violencia versus frivolidad? La irrupción de las fotografías de la Revolución en la prensa ilustrada mexicana. En M. C. Chaput y M. Peloille (Coords.), Sucesos, guerras, atentados: La escritura de la violencia y sus representaciones (pp. 99-111). París: Universidad de París.

Guzmán, M. L. (2010). El águila y la serpiente. En M. L. Guzmán, Obras completas I ( $4^{\mathrm{a}}$ ed.). México: Fondo de Cultura Económica.

Jablonska, A. y J. F. Leal. (1997). La revolución mexicana en el cine. Filmografía 19111917 (2 ed.), México: Universidad Pedagógica Nacional.

Knight, A. (2013). La Revolución mexicana: ¿burguesa, nacionalista o simplemente una ‘gran rebelión'? En A. Knight, Repensar la Revolución mexicana II (pp. 499-565). México: El Colegio de México.

Luna, A. de. (1984). La batalla y su sombra: La Revolución en el cine mexicano. México: Universidad Autónoma de Metropolitana-Xochimilco.

Mraz, J. (2009). Looking for Mexico: Modern Visual Culture and National Identity. Durham: Duke University Press.

Mraz, J. (2012). Photographing the Mexican revolution: commitments, testimonies, icons. Austin: University of Texas. 
Pick, Z. M. (2010). Constructing the Image of the Mexican Revolution: Cinema and the Ar chive. Austin: University of Texas Press.

Reyes, A. de los. (1986). Filmografía del cine mudo mexicano 1896-1920. México: Filmoteca de la Universidad Nacional Autónoma de México.

Sheridan, G. (Comp.). (1999). México en 1932: la polémica nacionalista. México: Fondo de Cultura Económica.

Siqueiros, D. A. (1924). Manifiesto de obreros técnicos, pintores y escultores. El Machete, 7, 4.

Vasconcelos, J. (1923). Invitación a los intelectuales y maestros para que se inscriban como misioneros. En Boletín de la Secretaría de Educación Pública (pp. 177-178). Ciudad de México: Secretaría de Educación Pública.

Wood, D. M. J. (2009). Memorias de una mexicana: la revolución como monumento fílmico. Secuencia. Revista de historia y ciencias sociales, 75, 145170 .

\section{¿Cómo citar este artículo?}

Avechuco Cabrera, D.(Enero-junio, 2018). Formas de recordar la guerra: violencia en la fotografía y el cine documental de la Revolución mexicana. Revista humanidades, 8(1), 1-22 doi:http://dx.doi.org/10.15517/h.v8i1.31466 